\title{
Effect of Irrigation and Nitrogen Levels on Productivity of Aerobic Rice in West Central Table Land Zone of Odisha, India
}

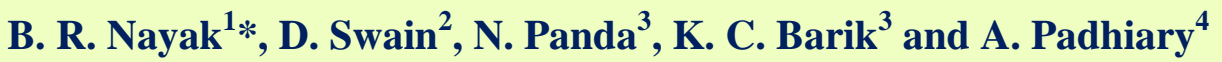 \\ ${ }^{1}$ Regional Research and Technology Transfer Station, OUAT, Chiplima \\ ${ }^{2}$ Regional Research and Technology Transfer Station, OUAT, Dhenkanal \\ ${ }^{3}$ OUAT, Bhubaneswar \\ ${ }^{4}$ Krishi Vigyan Kendra, OUAT, Chiplima, India \\ *Corresponding author
}

\section{A B S T R A C T}

Keywords

Aerobic rice, Irrigation regimes,

Nitrogen, Field

water use

efficiency, B:C ratio

Article Info

\section{Accepted:}

18 January 2020

Available Online:

10 February 2020
A field experiment was conducted on aerobic rice (Oryza sativa) during summer seasons of 2013 and 2014 at Regional Research and Technology Transfer Station, Chiplima, Sambalpur, Odisha in order to determine the effect of irrigation and nitrogen levels on yield, field water use efficiency and economics of aerobic rice (cv:Apo). The treatments consisted of four irrigations (irrigations at 3, 5, 7 and 9days interval) in the main-plots and four levels of nitrogen $(0,40,60$ and $80 \mathrm{~kg} \mathrm{~N}$ $\mathrm{ha}^{-1}$ ) in the sub-plots. The results revealed that interaction of irrigation at 3 day interval with $80 \mathrm{kgN} \mathrm{ha}^{-1}$ gave the higher grain yield (4.23t/ha))which was at par with 5 day interval with $80 \mathrm{kgN} \mathrm{ha}^{-1}$ and significantly superior to other interaction of irrigation intervals with nitrogen levels. The interaction of irrigation regime at 5 days interval with application of nitrogen at $80 \mathrm{~kg} \mathrm{ha}^{-1}$ produced the highest field

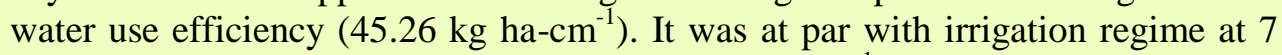
days interval with crop receiving nitrogen at $80 \mathrm{~kg} \mathrm{ha}^{-1}$ and significantly superior to other interaction between irrigation regimes with nitrogen levels. Thus, irrigation at 5 days interval with $80 \mathrm{~kg} \mathrm{~N} \mathrm{ha}^{-1}$ produced economically higher grain yield(4.23t/ha) and field water use efficiency $\left(45.26 \mathrm{~kg} \mathrm{ha-} \mathrm{cm}^{-1}\right)$ under aerobic rice.

\section{Introduction}

Rice (Oryza sativa L.) is the staple food for about $50 \%$ of the world population. The theme "Rice is life" is quite appropriate for India as this crop plays an important role in our national food security and is a source of livelihood for a millions of rural household.
Recently, there is an increasing scarcity of fresh water for agriculture particularly for rice cultivation due to decline in water levels in one hand and the demand of water for industries and other sectors on the other hand which threatens the sustainability of the irrigated rice ecosystem. The traditional rice production system not only leads to wastage 
of water but also causes environmental degradation and reduces the fertilizer use efficiency. Hence, by shifting gradually from traditional rice production to aerobic rice production system can mitigate the occurrence of water related problems. Aerobic rice culture is an emerging technology and revolutionary way of growing rice where the direct-seeded rice varieties with aerobic environment are grown in welldrained, un-puddled and non-saturated soils (aerobic soils).

Aerobic rice assumes greater importance in water scarcity area and increasing demand for rice. Nitrogen is the major and most limiting nutrients for growth and development as well as yield of rice in almost all environments. In low land ecosystems, approximately $30 \%$ of applied nitrogen is utilized by rice whereas in upland ecosystem, 40 to $60 \%$ of applied nitrogen utilized by rice (Shrestha, 2005). As aerobic rice culture is a new system, there is need to quantify the requirement of nitrogen for aerobic rice with particular reference to cultivars, location and management practices.

Odisha is having substantial area under rainfed/semidry dry rice and has a vast scope of growing rice under aerobic conditions. However, reliable information on vital agrotechniques for successful aerobic rice cultivation in this region is absolutely lacking. In this back drop, the present study was undertaken for standardization of irrigation interval and nitrogen dose under aerobic condition in west central table land zone of odisha.

\section{Materials and Methods}

The field experiment was carried out in the Regional Research and Technology Transfer Station, situated at Chiplima, Sambalpur, Odisha in summer season during 2013 and 2014 to investigate the "Effect of irrigation nitrogen interaction on yield, water use efficiency as well as economics of aerobic rice in west central table land zone of Odisha". Soil of the experimental field was sandy loam with acidic in reaction $(\mathrm{pH} 5.8)$, with organic carbon content of $0.38 \%$, and available $\mathrm{N}, \mathrm{P}$ and $\mathrm{K}$ contents of $187,15.4$ and $172 \mathrm{~kg} \mathrm{ha}^{-1}$, respectively. The moisture contents at field capacity and permanent wilting point were 19.4 and $8.4 \%$, respectively. The experiment was laid out in a split plot design with 3 replications.

The treatments consisted of four irrigation (irrigation at 3, 5, 7 and 9 days interval) in the main-plots and four levels of nitrogen $(0,40$, 60 and $80 \mathrm{~kg} \mathrm{ha}^{-1}$ ) in the sub-plots. The plot of size $30 \mathrm{~m}^{2}(6 \mathrm{~m} \times 5 \mathrm{~m})$ was used for the experiment. Seeds of (cv: APO) was manually sown@45kg ha ${ }^{-1}$ in furrows at $20 \mathrm{~cm}$ row spacing. Nitrogenous fertilizer was applied as per treatment. The grain yield $\left(\mathrm{t} \mathrm{ha}{ }^{-1}\right)$ was recorded on the net plot basis. Initially, after sowing, five irrigations of $3 \mathrm{~cm}$ depth were applied to all the plots irrespective of irrigation treatments for proper establishment of the seedlings till 20 DAS. Thereafter, irrigations were applied as per the treatments and $5 \mathrm{~cm}$ of water was applied during each irrigation. It may be noted that the depth of irrigation refers to the depth of water applied and not the depth of standing water on the plots. The rainfall during the crop growth period in both the years was sporadic. The total rainfall received were $65.9 \mathrm{~mm}$ and 9.1 $\mathrm{mm}$ in 2013 and 2014, respectively.

Hence, the intermittent rain falls were not taken into account for rescheduling of irrigation. However, the initial five common irrigations along with the rainfall (effective rainfall i.e.50\% of total rain fall) were taken into account for computation of crop water requirement under different treatments. The total number irrigations were 22, 15, 11 and 9 in $3,5,7$ and 9 days interval, respectively 
excluding the common five irrigations provided for crop establishment. The irrigation water was measured through $90^{\circ} \mathrm{V}$ notch weirs set up in the pucca channel of the experimental field. Water requirement was calculated by adding effective rainfall during crop growth period, amount of irrigation water applied and soil profile moisture contribution $(0-15 \mathrm{~cm})$.

Field water use-efficiency was calculated by dividing grain yield $\left(\mathrm{kg} \mathrm{ha}^{-1}\right)$ with the total amount of water required $(\mathrm{cm})$.From the pooled data, economics was worked out on the basis of prevailing market price of the produce and inputs used in the experiment. The analysis analyses of the recorded data for various parameters were carried out using the procedures described by Gomez and Gomez (1984).

\section{Results and Discussion}

\section{Grain yield}

Grain yield of rice increased significantly with decrease in irrigation interval up to 5 day and further decrease in irrigation interval did not prove beneficial (Table 1). The higher grain yield of $3.42 \mathrm{t} \mathrm{ha}^{-1}$ was produced with irrigation regime at 3 days interval. The increase in grain yield owing to irrigation at 3 day interval over 5,7 and 9 day interval were $6.1,22.5$ and $39.8 \%$, respectively. It might be due to reduced growth of plants, more number of emerged weeds and also the water stress suffered by the plants during reproductive phase that hampered the supply of photosynthates resulting in poor yield attributes.

This was in harmony with findings of Maheswari et al., (2008). The grain yield of rice increased significantly with increase in nitrogen levels during under study. Nitrogen $80 \mathrm{kgha}^{-1}$ produced higher grain yield of 3.58 $\mathrm{tha}^{-1}$. The increase in grain yield owing to 80 $\mathrm{kg} \mathrm{Nha}^{-1}$ over 60, 40 and $0 \mathrm{~kg} \mathrm{ha}^{-1}$ were 11.7 , 24.9 and $46.6 \%$, respectively. It might be enhanced stature of growth and yield attribute, forming larger sink size coupled with efficient translocation of photosynthates from source, which would have resulted in more number of filled grain there by finally reduced by grain yields. This was in accordance with the findings of Pradhan et al., (2014). The interaction of irrigation at 3 day interval with $80 \mathrm{kgN} \mathrm{ha}^{-1}$ gave the higher grain yield (Table 2) which was at par with 5 day interval with $80 \mathrm{kgN} \mathrm{ha}^{-1}$ and significantly superior to other interaction of irrigation intervals with nitrogen levels.

\section{Nitrogen Uptake by Crop}

The result showed that nitrogen uptake by crop decreased significantly with increase in irrigation interval. The total nitrogen uptake by crop ranged from $21.10 \mathrm{~kg} \mathrm{ha}^{-1}$ to $54.56 \mathrm{~kg}$ $\mathrm{ha}^{-1}$. However, nitrogen uptake by crop increased significantly with successive increase in nitrogen levels up to $80 \mathrm{~kg} \mathrm{ha}^{-1}$. The total nitrogen uptake by crop ranged from $19.34 \mathrm{~kg} \mathrm{ha}^{-1}$ to $57.90 \mathrm{~kg} \mathrm{ha}^{-1}$

\section{Water Use Efficiency}

The highest WUE of $36.0 \mathrm{~kg}$ ha- $\mathrm{cm}^{-1}$ (Table 1) was observed in the irrigation at 7days interval which was at par with 5day interval and significantly superior to 3 and 9day interval. The irrigation at 3 days interval gave lower water use efficiency $\left(26.80 \mathrm{~kg} \mathrm{ha}-\mathrm{cm}^{-1}\right)$ though grain yield was higher. This is due to consumption of more quantity of water. Similar findings have also been reported by Shekara et al., (2010). But in case of nitrogen, the FWUE increased significantly with increase in nitrogen up to the highest level $\mathrm{i}$. e. $80 \mathrm{~kg} \mathrm{ha}^{-1}\left(41.0 \mathrm{~kg}\right.$ ha-cm $\left.{ }^{-1}\right)$ It might be due to increase in grain yield with almost constant rate of applied water. Similar 
findings were obtained by Maheswari et al., (2008). The interaction of irrigation regime (Table 3) at 5 days interval with application of nitrogen at $80 \mathrm{~kg} \mathrm{ha}^{-1}$ produced the highest field water use efficiency $\left(45.26 \mathrm{~kg}\right.$ ha- $\left.\mathrm{cm}^{-1}\right)$.

It was at par with irrigation regime at 7 days interval with crop receiving nitrogen at $80 \mathrm{~kg}$ $\mathrm{ha}^{-1}$ and significantly superior to other interaction between irrigation regimes with nitrogen levels.

\section{Economics}

The maximum net return $\left(14.2 \times 10^{3} ₹ \mathrm{ha}^{-1}\right)$ and benefit: cost ratio (1.40) were obtained (Table 1)from the crop irrigated at 3day interval which was at par with irrigation at 5day interval and significantly superior to those of other irrigation regimes. It might be due to higher grain yield with higher irrigation levels.

Table.1 Effect of irrigation and nitrogen levels on grain yield, water use efficiency (WUE), nitrogen uptake and economics of aerobic rice (pooled mean)

\begin{tabular}{|c|c|c|c|c|c|}
\hline Treatments & $\begin{array}{l}\text { Grain yield } \\
\left(\mathrm{t} \mathrm{ha}^{-1}\right)\end{array}$ & $\begin{array}{c}\text { WUE } \\
\left({\left.\mathrm{kg} \mathrm{ha}-\mathrm{cm}^{-1}\right)}^{-1}\right.\end{array}$ & $\begin{array}{c}\text { Nitrogen uptake by } \\
\text { crop } \\
\left(\mathbf{k g ~ h a}^{-1}\right)\end{array}$ & $\begin{array}{l}\text { Net return } \\
\left(₹ \times 10^{3 ₹}\right. \\
\left.h^{a^{-1}}\right)\end{array}$ & $\begin{array}{l}\text { B:C } \\
\text { ratio }\end{array}$ \\
\hline \multicolumn{5}{|c|}{ Irrigation interval(days) } & \\
\hline 3 & 3.42 & 26.8 & 54.56 & 14.2 & 1.40 \\
\hline 5 & 3.21 & 34.5 & 46.60 & 11.7 & 1.34 \\
\hline 7 & 2.65 & 36.0 & 32.96 & 4.3 & 1.12 \\
\hline 9 & 2.06 & 32.3 & 21.10 & -3.9 & 0.88 \\
\hline $\operatorname{SEm} \pm$ & 0.07 & 0.8 & 1.33 & 1.0 & 0.03 \\
\hline $\mathrm{CD}(\mathbf{P}=(\mathbf{0 . 0 5})$ & 0.23 & 2.6 & 4.62 & 3.1 & 0.09 \\
\hline \multicolumn{5}{|c|}{ Nitrogen levels( $\left.\mathrm{kg} \mathrm{ha}^{-1}\right)$} & \\
\hline $\mathbf{0}$ & 1.91 & 22.2 & 19.34 & -6.0 & 0.82 \\
\hline 40 & 2.69 & 30.6 & 33.00 & 4.3 & 1.12 \\
\hline 60 & 3.16 & 36.2 & 44.98 & 11.0 & 1.13 \\
\hline 80 & 3.58 & 40.5 & 57.90 & 16.8 & 1.48 \\
\hline $\operatorname{SEm} \pm$ & 0.06 & 0.5 & 0.88 & 0.8 & 0.02 \\
\hline $\mathrm{CD}(\mathbf{P}=0.05)$ & 0.17 & 1.3 & 2.57 & 2.3 & 0.07 \\
\hline
\end{tabular}

Table.2 Interaction effect of irrigation regimes and nitrogen levels on grain yield $\left(\mathrm{t} \mathrm{ha} \mathrm{h}^{-1}\right)$ of aerobic rice (pooled mean)

\begin{tabular}{|c|c|c|c|c|}
\hline \multirow{2}{*}{$\begin{array}{c}\text { Irrigation } \\
\text { intervals(days) }\end{array}$} & \multicolumn{4}{|c|}{ Nitrogen levels $\left(\mathrm{kg} \mathrm{ha}^{-1}\right)$} \\
\hline & 0 & 40 & 60 & 80 \\
\hline 3 & 2.30 & 3.35 & 3.72 & 4.39 \\
\hline 5 & 2.03 & 2.94 & 3.64 & 4.23 \\
\hline 7 & 1.78 & 2.50 & 3.04 & 3.27 \\
\hline \multirow[t]{2}{*}{9} & 1.58 & 1.96 & 2.24 & 2.44 \\
\hline & \multicolumn{2}{|c|}{ I within $\mathrm{N}$} & \multicolumn{2}{|c|}{$\mathrm{N}$ within I } \\
\hline $\operatorname{SEm}( \pm)$ & \multicolumn{2}{|c|}{0.12} & \multicolumn{2}{|c|}{0.08} \\
\hline $\mathrm{CD}(\mathrm{P}=\mathbf{0 . 0 5})$ & \multicolumn{2}{|c|}{0.36} & \multicolumn{2}{|c|}{0.24} \\
\hline
\end{tabular}


Table.3 Interaction effect of irrigation regimes and nitrogen levels on field water use (kg ha$\mathrm{cm}^{-1}$ ) of aerobic rice (pooled mean)

\begin{tabular}{|c|c|c|c|c|}
\hline \multirow{2}{*}{$\begin{array}{c}\text { Irrigation } \\
\text { intervals(days) }\end{array}$} & \multicolumn{4}{|c|}{ Nitrogen levels $\left(\mathrm{kg} \mathrm{ha}^{-1}\right)$} \\
\hline & 0 & 40 & 60 & 80 \\
\hline 3 & 17.96 & 26.09 & 29.02 & 34.19 \\
\hline 5 & 21.77 & 31.56 & 39.03 & 45.26 \\
\hline 7 & 24.23 & 34.02 & 41.36 & 44.41 \\
\hline \multirow[t]{2}{*}{9} & 24.85 & 30.81 & 35.22 & 38.32 \\
\hline & \multicolumn{2}{|c|}{ I within $\mathrm{N}$} & \multicolumn{2}{|c|}{$\mathrm{N}$ within I } \\
\hline SEm ( \pm$)$ & \multicolumn{2}{|c|}{1.21} & \multicolumn{2}{|c|}{1.09} \\
\hline $\mathrm{CD}(\mathrm{P}=\mathbf{0 . 0 5})$ & \multicolumn{2}{|c|}{3.53} & \multicolumn{2}{|c|}{3.14} \\
\hline
\end{tabular}

Similar findings obtained Shekara et al., (2010). The maximum net return $\left(27.9 \times 10^{3} ₹\right.$ $\mathrm{ha}^{-1}$ )and benefit: cost ratio (1.48) in aerobic rice were obtained at $80 \mathrm{kgN} \mathrm{ha}^{-1}$.It was significantly superior to that of other nitrogen levels. It might be due to higher grain yield with higher $\mathrm{N}$ levels. Similar findings obtained Reddy et al., (2012) and Pradhan et al., (2014).

It was concluded that crop receiving irrigation at 5 days interval with $80 \mathrm{kgN} \mathrm{ha}^{-1}$ produced economically higher grain yield(4.23t $\left.\mathrm{ha}^{-1}\right)$ and field water use efficiency $\left(34.5 \mathrm{~kg} \mathrm{ha}-\mathrm{cm}^{-1}\right)$. Aerobic rice has responded up to higher dose of nitrogen i.e. $80 \mathrm{~kg} \mathrm{ha}^{-1}$ that means still optimum dose could be higher

\section{References}

Gomez, A. K and Gomez, A. A.1984. Statistical procedures for agricultural research $\left(2^{\text {nd }} E d.\right)$. John Wiley \& Sons.
Maheswari, J., Bose, J., Sangeetha, S. P., Sanjutha, S and Sathyapriya, R. 2008.Irrigation regimes and N levels influence chlorophyll, leaf area index, proline and soluble protein content of aerobic rice. International Journal of Agricultural Research 3 (4), 307-09.

Pradhan, A., Thakur, A and Sonboir, H. L. 2014.Response of rice varieties to different levels of nitrogen under rainfed aerobic system. Indian Journal of Agronomy 59, 76-79.

Shekara, B. G.,Sharnappa and Krishnamurty, N., 2010. Effect of irrigation schedules on growth and yield of aerobic rice (Oryzasativa) under varied levels of farmyard manure in Cauvery command area. Indian Journal of Agronomy55(1),35-39.

Shrestha, R. K andMaskey, S. L.2005. Associative Nitrogen Fixation in Lowland Rice. Nepal Agriculture Research 6, 112-121

\section{How to cite this article:}

Nayak B. R, D. Swain, N. Panda, K. C. Barik and Padhiary. A. 2020. Effect of Irrigation and Nitrogen Levels on Productivity of Aerobic Rice in West Central Table Land Zone of Odisha, India. Int.J.Curr.Microbiol.App.Sci. 9(02): 2493-2497. doi: https://doi.org/10.20546/ijcmas.2020.902.283 